\section{Commentary: Robotic first rib resection-Building the next pillar}

\author{
Richard Lazzaro, MD, and Byron Patton, MD
}

When thoracic surgeons consider the anatomic scope of their practice, several pillars come to mind: lung, esophagus, and mediastinum. Few would list the thoracic outlet as a major contribution. The reasons for this are multifactorial. Thoracic outlet syndromes are uncommon, difficult to diagnose, and litigious (contentious disease diagnosis as well as may result in litigation). First rib resections involve unfamiliar anatomy and challenging exposure. The advent of minimally invasive transthoracic resection, however, has the potential to change this perspective.

In his 1962 presidential address to the Annual Meeting of the American Association for Thoracic Surgery, Clagett ${ }^{1}$ discussed these issues in detail, declaring, "Although patients with these syndromes have not been the concern of thoracic surgeons in the past, surgical conditions involving this anatomic area are legitimately the province of thoracic surgeons." Few thoracic surgeons, however, took this declaration to heart. In fact, a study from 2017 of National Surgical Quality Improvement Program data found that 90\% of these procedures were performed by vascular surgeons. ${ }^{2}$

Numerous surgical procedures have been performed through the years, most notably the original supraclavicular approach, clavicular resection, and then the transaxillary approach described by $\operatorname{Roos}^{3}$ in 1966. In his presidential address, Clagett ${ }^{1}$ advocated for a posterior approach because of thoracic surgeons" "considerable experience in removing the first rib safely in the performance of thoracoplasty for tuberculosis." Few surgeons today, however, would be able to relate to that experience.

In this issue of JTCVS Techniques, Burt and colleagues ${ }^{4}$ present an elegant robot-assisted transthoracic approach, broken down into 12 simple steps. The text of the article

From the Department of Cardiothoracic Surgery, Lenox Hill Hospital, New York, NY. Disclosures: Authors have nothing to disclose with regard to commercial support.

Received for publication Dec 15, 2019; revisions received Dec 15, 2019; accepted for publication Jan 3, 2020; available ahead of print Feb 6, 2020.

Address for reprints: Richard Lazzaro, MD, Department of Cardiothoracic Surgery, Lenox Hill Hospital, 130 E 77th St, New York, NY 10075 (E-mail: rlazzaro@ northwell.edu).

JTCVS Techniques 2020;1:110-1

2666-2507

Copyright (C) 2020 The Author(s). Published by Elsevier Inc. on behalf of The American Association for Thoracic Surgery. This is an open access article under the CC BY-NC-ND license (http://creativecommons.org/licenses/by-nc-nd/4.0/).

https://doi.org/10.1016/j.xjtc.2020.01.006

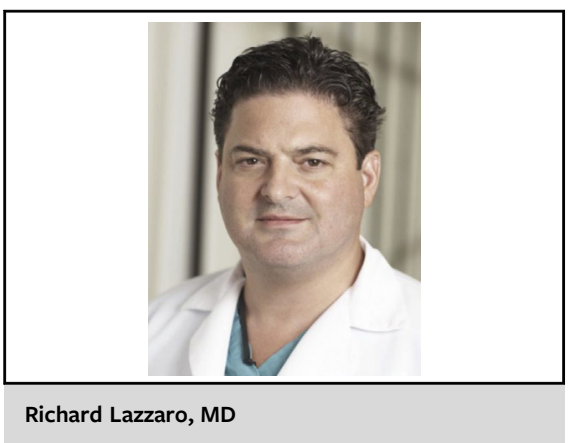

CENTRAL MESSAGE

In minimally invasive approach to

first rib resection, better visuali-

zation enhances learning

through video deconstruction of

an operation.

is accompanied by short videos demonstrating the technique. This method is especially effective at taking a complex procedure and distilling it to its critical steps. Tips and variations for challenging or atypical cases are also discussed. The most compelling reasons to adopt this technique are the outstanding exposure, the lack of manipulation of neurovascular structures, and the ability to perform fine dissection required for venolysis and neurolysis. Other open techniques often have significantly limited exposure, with only the surgeon having adequate visualization. The video-assisted thoracoscopic surgical platform allows the entire surgical team to see each step clearly. The critical vascular and neural structures are clearly defined, allowing all impinging fibrous tissue to be stripped away after removal of the first rib.

Although the merits of this approach relative to open techniques are yet to be directly studied, it may offer additional benefits. Teaching first rib resection is challenging when the surgeon is working through a small opening, especially in a muscular or obese patient. An assistant is often holding the arm, with another assistant holding retractors. All these factors are removed in a robotic approach. The surgeon and trainee can work together in dual consoles, allowing the surgeon to demonstrate specific techniques and the trainee to replicate them. This standardized, stepwise method of teaching will inevitably lead to safer, more reproducible operations.

Thoracic outlet syndromes remain a challenge in medicine for a multitude of reasons, but this article and 
videos will undoubtedly ease the stress on both teacher and student. Future surgeons will improve on these steps, and technology will make these procedures easier and safer. It is to be hoped that this will also lead to greater adoption by thoracic surgeons. Perhaps it is the first block in a new pillar created by the thoracic surgical community.

\section{References}

1. Clagett OT. Research and prosearch. J Thorac Cardiovasc Surg. 1962;44:153-66.

2. Rinehardt EK, Scarborough JE, Bennett KM. Current practice of thoracic outlet decompression surgery in the United States. J Vasc Surg. 2017;66:858-65.

3. Roos DB. Transaxillary approach for first rib resection to relieve thoracic outlet syndrome. Ann Surg. 1966;163:354-8.

4. Burt BM, Palivela N, Karimian A, Goodman MB. Transthoracic robotic first rib resection: twelve steps. J Thorac Cardiovasc Surg Tech. 2020;1:104-9. 